\title{
Bacterial vaginosis: comparison of Pap smear and microbiological test results
}

\author{
Çiğdem Tokyol ${ }^{1}$, Orhan Cem Aktepe ${ }^{2}$, Arif Serhan Cevrioğlu³, Mustafa Altındiş ${ }^{2}$ \\ and Fatma Hüsniye Dilek ${ }^{1}$ \\ ${ }^{1}$ Department of Pathology; ${ }^{2}$ Department of Microbiology and ${ }^{3}$ Department of Gynecology and Obstetrics, \\ Faculty of Medicine, Afyon Kocatepe University, Afyon, Turkey
}

\begin{abstract}
Our purpose was to determine the reliability of the Pap smear in making the diagnosis of bacterial vaginosis and to examine the characteristics of Pap smear vs vaginal culture in diagnosis of bacterial vaginosis, with the vaginal Gram stain used as the diagnostic standard. We performed a prospective, blinded study involving 245 women who referred to the Department of Gynecology and Obstetrics in our hospital for routine genital examination between September 2001 and September 2002. Exclusion criteria included vaginal bleeding and pregnancy. Each patient had standard Pap smear, Gram-stained vaginal smear and culture of vaginal swab. The sensitivity, specificity, positive predictive value, negative predictive value, and diagnostic value of Pap smear and vaginal culture results were determined with Gram stain used as the standard for diagnosis of bacterial vaginosis. Using Gram stain diagnosis of bacterial vaginosis as the standard, Pap smear and vaginal culture test results had sensitivity of $\mathbf{4 3 . 1}$ and $77.8 \%$, specificity of $\mathbf{9 3 . 6}$ and $97.7 \%$, positive predictive value of 73.8 and 93.3\%, negative predictive value of 79.8 and $91.4 \%$, diagnostic value of 78.8 and $91.8 \%$, respectively, for the diagnosis of bacterial vaginosis. Compared to the microbiological test results, Pap smear is not sensitive enough for screening of bacterial vaginosis. However, because of its high specificity, it may be an adequate diagnostic criteria when it is positive.

Modern Pathology (2004) 17, 857-860, advance online publication, 9 April 2004; doi:10.1038/modpathol.3800132
\end{abstract}

Keywords: bacterial vaginosis; Pap smear; Gram stain; vaginal culture

Bacterial vaginosis was first described by Gardner and Dukes. ${ }^{1}$ They regarded Gardnerella vaginalis as the etiologic agent of bacterial vaginosis, but this concept has been changed. Bacterial vaginosis is characterized by a shift in the vaginal flora from the dominant flora of Lactobacillus spp. to a mixed vaginal flora that includes $G$. vaginalis, Bacterioides spp., Mobiluncus spp. and Mycoplasma hominis. ${ }^{2,3}$ The vaginal Gram-stained smears has been evaluated extensively as a diagnostic test for bacterial vaginosis. $^{4}$

The Pap smear is used commonly as cytologic screening test for eradication of precancerous lesions. ${ }^{5}$ The success of cytological screening for cervical cancer has made the Pap smear a routine procedure. ${ }^{6}$ It has also been evaluated as a diagnostic test for bacterial vaginosis, but the results of

Correspondence: Ç Tokyol MD, Dumlupinar mah. 2. Cad, No: 26/ 11 03200, Afyon, Turkey.

E-mail: ctokyol@hotmail.com

Presented at the 29th European Congress of Cytology, October 5.08.2003, Prague.

Received 14 July 2003; accepted 15 January 2004; published online 9 April 2004 these studies are contradictory. The objective of our study is to determine the reliability of the cervical smear in making the diagnosis of bacterial vaginosis and to examine the characteristics of Pap smear vs vaginal culture in diagnosis of bacterial vaginosis, with the vaginal Gram stain used as the diagnostic standard.

\section{Materials and methods}

We performed a prospective, blinded study involving 245 women who referred to the Department of Obstetrics and Gynecology in our hospital for routine genital control between September 2001 and September 2002. Each patient had standard Pap smear, Gram-stained vaginal smear and culture of vaginal swab.

\section{Pap Smear and Evaluation}

Pap smears, including squamocolumnar junction, were performed with endocervical brush, fixed in 95\% ethanol and stained by the Papanicolaou method. They were evaluated under the Bethesda 
system guidelines for specimen adequacy and general categorization. Adequate transformation zone sampling was defined as the presence of at least 10 well-preserved endocervical or squamous metaplastic cells singly or in groups. ${ }^{7}$ If there was a filmy background of small coccobacilli, individual squamous cells with a layer of coccobacilli along the margins of the cell membranes, and conspicuious absence of lactobacilli, the smear was evaluated as positive for bacterial vaginosis (Figures 1 and 2). Smears displaying the pattern characteristic of bacterial vaginosis were reported as 'shift in flora suggestive of bacterial vaginosis'. The smears were later re-examined for the presence of bacterial vaginosis by one pathologist who was blinded to the microbiological test results.

\section{Gram Staining and the Scoring System}

The vaginal swab specimens were taken from the posterior fornix. They were smeared directly on glass slides and air dried for a standard Gram stain.

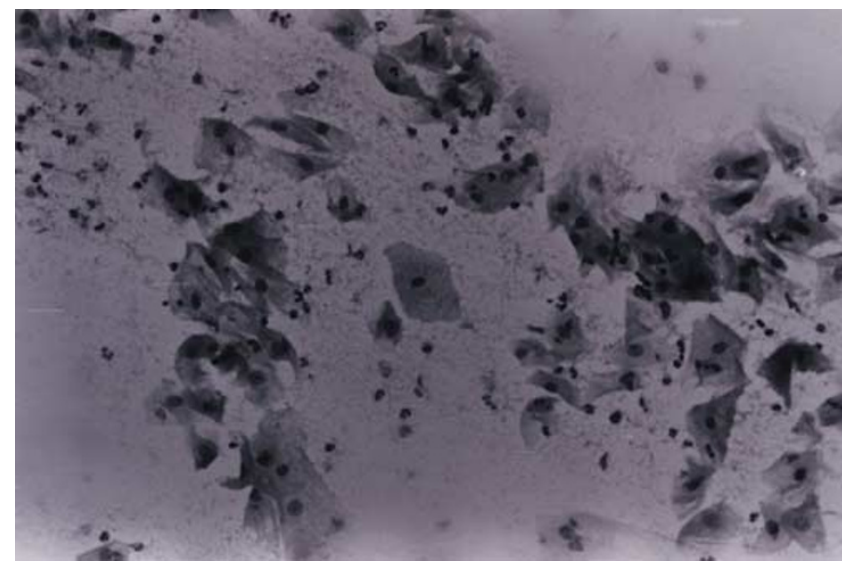

Figure 1 Smear displaying the characteristic pattern of bacterial vaginosis: a filmy background of small coccobacilli $(\mathrm{HE}, \times 200)$.

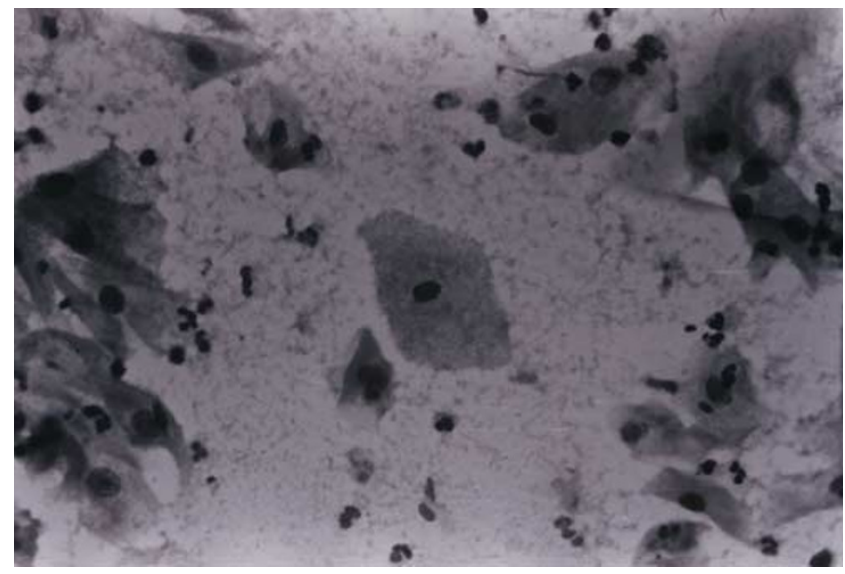

Figure 2 Individual squamous cell with a layer of coccobacilli along the margins of the cell membranes $(\mathrm{HE}, \times 400)$.
Gram-stained slides were evaluated according to the Nugent et $a l,{ }^{4}$ by a microbiologist who was blinded to the results of Pap smears. ${ }^{4}$ Each slide was examined under an oil immersion objective ( $\times 1000$ magnification) for the following morphotypes: large Gram-positive rods (Lactobacillus morphotypes), small Gram-negative/variable rods (Gardnerella and Bacterioides morphotypes), and curved Gram-negative/variable rods (Mobiluncus morphotypes). These morphotypes were used to develop a 0- - 10-point scoring system for the diagnosis of bacterial vaginosis (Table 1). Scores were classified into three groups (Table 2). For the purpose of this study, patients with intermediate scores were considered to be negative.

\section{Vaginal Culture Studies}

The vaginal swabs collected simultaneously were cultured on 5\% blood agar, eosin methylene blue agar and Sabouraud dextrose agar. The plates were evaluated following $24-48 \mathrm{~h}$ incubation at $37^{\circ} \mathrm{C}$ in microaerophilic conditions. Positive cultures for $G$. vaginalis were defined as bacterial vaginosis.

\section{Statistical Analysis}

The results of the Pap smears and vaginal cultures were analyzed and compared statistically. The sensitivity, specificity, positive predictive value, negative predictive value, and diagnostic value of Pap smear and vaginal culture were determined with Gram stain used as the gold standard for diagnosis of bacterial vaginosis.

Table 1 Scoring system for Gram-stained vaginal smears

\begin{tabular}{lccc}
\hline Score & $\begin{array}{c}\text { Lactobacillus } \\
\text { morphotypes }\end{array}$ & $\begin{array}{c}\text { Gardnerella } \\
\text { and } \\
\text { Bacteroides } \\
\text { spp. morphotypes }\end{array}$ & $\begin{array}{c}\text { Curved } \\
\text { Gram-variable rods }\end{array}$ \\
\hline 0 & $4+$ & 0 & 0 \\
1 & $3+$ & $1+$ & $1+$ or $2+$ \\
2 & $2+$ & $2+$ & $3+$ or $4+$ \\
3 & $1+$ & $3+$ & \\
4 & 0 & $4+$ & \\
\hline
\end{tabular}

$1+,<1 / 1000 \times ; 2+, 1-5 / 1000 \times ; 3+, 6-30 / 1000 X ; 4+>30 / 1000 \times$.

Table 2 Classification of the scores

\begin{tabular}{ll}
\hline Score & Group \\
\hline $0-3$ points & Normal \\
$4-6$ points & Intermediate \\
$7-10$ points & Bacterial vaginosis
\end{tabular}




\section{Results}

There were 245 patients. The patient age range was 19-77 years, with a mean age of 41.1 years. Of the 245 Pap smears, 180 included transformation zone component, 20 were cuff smears. In only one smear, which was positive for bacterial vaginosis, highgrade squamous intraepithelial lesion was determined. The other patients did not have any epithelial cell abnormalities.

According to the criteria of Nugent et $a l,{ }^{4}$ Gram stains of the $72(29.4 \%)$ patients were positive for bacterial vaginosis, 120 (49\%) had negative Gram stains, and $53(21.6 \%)$ had intermediate Gram stains. Of the 72 patients with positive Gram stains, 31 had shift in flora suggestive of bacterial vaginosis in terms of Pap smear findings, 41 had negative Pap smears. In the microbiological evaluation of the samples, 56 had positive culture results for $G$. vaginalis, and 16 had negative cultures. Using Gram stain diagnosis of bacterial vaginosis as the standard, Pap smear and vaginal culture test results had sensitivity of 43.1 and $77.8 \%$, specificity of 93.6 and $97.7 \%$, positive predictive value of 73.8 and $93.3 \%$, negative predictive value of 79.8 and $91.4 \%$, diagnostic value of 78.8 and $91.8 \%$, respectively.

\section{Discussion}

Bacterial vaginosis is a commonly encountered cause of vaginitis. The most common form of vaginitis in the US is bacterial vaginosis. ${ }^{8}$ The average incidence of bacterial vaginosis varies; the rates are $10-35 \%$ in patients visiting gynecological wards, $10-30 \%$ in patients visiting obstetric wards and $20-60 \%$ in patients visiting services of sexually transmitted disease. ${ }^{9}$ Among the women we investigated, $29.4 \%$ of them had bacterial vaginosis. This prevalance is higher than our previous study result, which was $9.1 \% .^{10}$ Bacterial vaginosis is associated with many obstetric and gynecologic complications, including preterm labor, preterm premature rupture of membranes, chorioamnionitis, puerperal endometritis, pelvic inflammatory disease, urinary tract infection, postoperative cellulitis, and cervical dysplasia. ${ }^{11,12}$

The chief complaint of patients with bacterial vaginosis is malodorous vaginal discharge. Approximately $50 \%$ of patients with bacterial vaginosis do not have any symptoms. ${ }^{9}$ The diagnosis of bacterial vaginosis is usually established according to the clinical criteria or microbiological tests. Bacterial vaginosis is often misdiagnosed using clinical criteria because the components are subjective and dependent on the performance of the clinician and available equipment. ${ }^{4,13}$ The use of vaginal cultures for $G$. vaginalis is limited by the test's poor specificity. ${ }^{14} G$. vaginalis commonly occurs in the vagina of women without bacterial vaginosis and bacterial vaginosis may be produced by microorgan- isms other than G. vaginalis. ${ }^{15}$ The results of the study by Nugent et $a l^{4}$ indicated that the criteria for diagnosis of bacterial vaginosis using Gram stain can be produced reliably by different centres and microbiologists. It is also reliable when evaluating an asymptomatic population. ${ }^{13}$

Platz-Christensen et a ${ }^{15}$ reported that detection of clue cells in Pap smears showed a sensitivity of $90 \%$ and a specificity of $97 \%$ when compared with clinical diagnosis of bacterial vaginosis. They did not specify whether they obtained their specimens from the cervix or the vagina.

Schnadig et $a l^{16}$ reported a high correlation between Pap smears and Gram smears for the diagnosis of bacterial vaginosis. Pap smears were more accurate than wet preparations for identifying clue cells. They suggested that lactobacilli pseudoclue cells were probably one cause for false-positive identifications of clue cells in wet preparations.

Davis et $a l^{14}$ reported that compared to the Gram stain, cervical cytologic test results had a sensitivity of $55 \%$, specificity of $98 \%$, a positive predictive value of $96 \%$, and a negative predictive value of $78 \%$.

Hillier $^{17}$ stated that in their experience, diagnosis of bacterial vaginosis by examination of Pap smears is less specific than the Gram stain of vaginal fluid because standardized criteria for the evaluation of Pap smears have not been routinely applied. They believe that bacterial vaginosis is diagnosed best on the basis of vaginal and not cervical specimens.

We determined that Pap smear has a sensitivity of $43.1 \%$, and a specificity of $93.6 \%$ for the diagnosis of bacterial vaginosis when compared to Gram stain. We compared the cervical smear with Gram stain, because clinical criteria are subjective and have interpractitioner variability. We used the diagnostic criteria of the Bethesda system to diagnose bacterial vaginosis on cervical smear, because, clue cells alone are not sufficient to diagnose bacterial vaginosis. As it is a routine cytologic procedure, we evaluated the cervical, not vaginal smear for the diagnosis of bacterial vaginosis. This can also explain the low sensitivity we determined.

We determined that vaginal culture has a sensitivity of $77.8 \%$, and a specificity of $97.7 \%$ for the diagnosis of bacterial vaginosis when compared to Gram stain.Vaginal cultures for G. vaginalis are often the primary laboratory test available for the diagnosis of vaginitis. Although it has a sensitivity of 83-94\% among the women who have clinical signs of bacterial vaginosis, ${ }^{18-20}$ the usefulness of these cultures is doubtful. ${ }^{17} \mathrm{G}$. vaginalis commonly occurs in the vaginas of women without bacterial vaginosis and bacterial vaginosis may be produced by microorganisms other than $G$. vaginalis. According to our results, with a specificity of $97.7 \%$, and a positive predictive value of $93.3 \%$, it seems likely that, vaginal culture is an adequate diagnostic criteria when it is positive. 
One of the most important complications of bacterial vaginosis is cervical dysplasia. It is hypothesized that bacterial vaginosis could be important in the development of neoplasia of the cervix, because the abnormal microflora in this condition produce carcinogenic nitrosamins. ${ }^{21}$ In this study, only one of the patients had high-grade cervical intraepithelial neoplasia and both of her test results were positive for bacterial vaginosis. The hypothesis above should be tested among the women in whom cervical neoplasia is more prevalant.

Although cervical smear is a routine procedure for screening cervical cancer, it is less sensitive than microbiological test results for screening of bacterial vaginosis, particularly when compared with Gram stain evaluation. However, because of its high specificity, it may be an adequate diagnostic criteria when it is positive.

\section{References}

1 Gardner HL, Dukes CD. Haemophilus vaginalis vaginitis. Am J Obstet Gynecol 1955;69:962-976.

2 Martius J, Krohn MA, Hillier SL, et al. Relationship of vaginal Lactobacillus species, cervical Chlamydia trachomatis, and bacterial vaginosis to preterm birth. Obstet Gynecol 1988;71:89-95.

3 Mazzuli T, Simor AE, Low DE. Reproducibility of interpretation of Gram-stained vaginal smears for the diagnosis of bacterial vaginosis. J Clin Microbiol 1990;28:1506-1508.

4 Nugent RP, Krohn MA, Hillier SL. Reliability of diagnosing bacterial vaginosis is improved by a standardized method of Gram stain interpretation. J Clin Microbiol 1991;29:297-301.

5 Koss LG. Epidermoid carcinoma of the uterine cervix and related precancerous lesions. Part I: Natural history, definitions, behaviour, and experimental studies. In: Diagnostic Cytology and its Histopathologic Bases, 4th edn. Vol. 1. J.B. Lippincott Company: Philadelphia, PA, 1992, pp 371-423.

6 Sherman ME. Cytopathology. In: Kurman RJ (ed). Blaustein's Pathology of the Female Genital Tract, 4th edn. Springer-Verlag: USA, 1994, pp 1097-1130.
7 Smith JHF. Bethesda 2001. Cytopathology 2002;13: $4-10$.

8 Soper DE. Genitourinary infections and sexually transmitted disease. In: Berek JS (ed). Novak's Gynecology, 12th edn. Mass Publishing Co.: Egypt, 1996, pp 429-445.

9 Georgijevic A, Cjukic-Ivancevic S, Bujko M. Bacterial vaginosis. Epidemiology and risk factors. Srp Arh Celok Lek 2000;128:29-33.

10 Tokyol Ç, Aktepe OC, Aktepe F, et al. Vajinal infeksiyonların tanısında servikal sitoloji ve gram boyası sonuçlarının karşılaştırılması. Türk Patoloji Dergisi 2001;17:72-74.

11 Thomason JL, Gelbart SM, Scaglione NJ. Bacterial vaginosis: current review with indications for asymptomatic therapy. Am J Obstet Gynecol 1991;165: 1210-1217.

12 Clark P, Kurtzer T, Duff P. Role of bacterial vaginosis in peripartum infections. Infect Dis Obstet Gynecol 1994;2:179-183.

13 Mastrobattista JM, Bishop KD, Newton ER. Wet smear compared with Gram stain diagnosis of bacterial vaginosis in asymptomatic pregnant women. Obstet Gynecol 2000;96:504-506.

14 Davis JD, Connor EE, Clark P, et al. Correlation between cervical cytologic results and Gram stain as diagnostic tests for bacterial vaginosis. Am J Obstet Gynecol 1997;177:532-535.

15 Platz-Christensen JJ, Larsson PG, Sundström E, et al. Detection of bacterial vaginosis in Papanicolaou smears. Am J Obstet Gynecol 1989;160:132-133.

16 Schnadig VJ, Davie KD, Shafer Sk, et al. The cytologist and bacteriosis of the vaginal-ectocervical area: clues, commas and confusion. Acta Cytol 1989;33:287-297.

17 Hillier SL. Diagnostic microbiology of bacterial vaginosis. Am J Obstet Gynecol 1993;169:455-459.

18 Amsel R, Totten PA, Spiegal CA, et al. Nonspecific vaginitis: diagnostic criteria and microbial and epidemiologic associations. Am J Med 1983;74: 14-22.

19 Eschenbach DA, Hillier SL, Critchlow C, et al. Diagnosis and clinical manifestations of bacterial vaginosis. Am J Obstet Gynecol 1988;158:819-828.

20 Krohn MA, Hillier SL, Eschenbach DA. Comparison of methods for diagnosing bacterial vaginosis among pregnant woman. J Clin Microbiol 1989;27:1266-1271.

21 Pavic N. Is there a local production of nitrosamines by the vaginal microflora in anaerobic vaginosis/trichomoniasis? Med Hypotheses 1984;15:433-436. 